Prosiding Seminar Nasional Teknologi Informasi dan Kedirgantaraan : Transformasi Teknologi untuk Mendukung Ketahanan Nasional, Yogyakarta, 13 Desember 2018

SENATIK 2018, Vol. IV, ISBN 978-602-52742-0-6

DOI: http://dx.doi.org/10.28989/senatik.v4i0.263

\title{
MONITORING SYSTEM OF STUDENT PERFORMANCE USING DATA WAREHOUSE (CASE STUDY: INSTITUT TEKNOLOGI SUMATERA) \\ Ahmad Luky Ramdani ${ }^{1)}$, Raidah Hanifah ${ }^{(2)}$, Okta Pilopa ${ }^{(3)}$ \\ Program Studi Teknik Informatika, Institut Teknologi Sumatera \\ Lampung Selatan, Bandar Lampung \\ Email: ${ }^{1}$ ahmadluky@if.itera.ac.id
}

\begin{abstract}
Improving the quality of learning is one of the things that must be achieved in the college academic process. To achieve this, monitoring and evaluation of the results of the learning process is needed, namely by looking at student performance. Based on this, the research aims to develop a university data warehouse with student performance objects that will be used by the board application for the monitoring process. The application was successfully developed with several main features, namely: a) displaying the number of students based on year, region and the entrance to college, $b$ ) displaying a comparison of the number of students in each academic year based on student status, d) display student performance every academic year and e) KPI values based on needs analysis. These features have been tested using the blackbox approach and the test results show that the features work properly and produce outputs in corresponding to the test scenario.
\end{abstract}

Keyword: Student performance, Data Warehouse, Dashboard, Open Source Software

Abstrak

Peningkatan kualitas pembelajaran merupakan salah satu hal yang harus dicapai dalam proses akademik perguruan tinggi. Untuk mencapai hal tersebut diperlukan monitoring dan evaluasi terhadap hasil proses pembelajaran, yaitu dengan melihat performansi peserta didik. Berdasarkan hal tersebut penelitian ini bertujuan mengembangkan data warehouse perguruan tinggi dengan objek perfomansi mahasiswa yang akan digunakan oleh aplikasi dahsboard untuk proses monitoring. Aplikasi berhasil dikembangkan dengan beberapa fitur utama yang terkait dengan performansi mahasiswa yaitu: a) menampilkan jumlah mahasiswa berdasarkan tahun masuk, asal daerah dan jalur masuk, b) perbandingan jumlah mahasiswa pada setiap tahun akademik berdasarkan status mahasiswa, c) menampilkan mahasiswa yang bermasalah pada tahun pertama perkuliahan, d) menampilkan performansi mahasiswa setiap tahun akademik dan e) nilai KPI berdasarkan analisis kebutuhan. Fitur-fitur ini dilakukan pengujian dengan pendekatan blackbox dan hasil pengujian menunjukkan berjalan dengan baik sesuai dengan skenario pengujian.

Kata Kunci : Performansi mahasiswa, Data Warehouse, Dashboard, Open Source Software

\section{Pendahuluan}

Meningkatkan proses pembelajaran merupakan salah satu hal yang harus dicapai dalam proses akademik perguruan tinggi [1]. Untuk mewujudkan hal tersebut, yang harus dilakukan oleh perguruan tinggi adalah proses monitoring dan evaluasi hasil dari proses pembelajaran yaitu dengan melihat performansi peserta didik (mahasiswa).

Bidang akademik merupakan salah satu komponen dalam perguruan tinggi yang memiliki kontribusi dalam meningkatkan proses pembelajaran. Bidang akademik menyimpan data mahasiswa yang berkaitan dengan proses pembelajaran. Data mahasiswa merupakan salah satu yang penting dalam proses bisnis perguruan tinggi. Data dapat memberikan 
informasi yang akan digunakan dalam proses pengambilan keputusan seperti terkait dengan strategi perguruan tinggi dalam meningkatkan kualitas lulusan. Namun pada realitasnya data yang seharusnya dapat digunakan untuk menghasilkan informasi belum termanfaatkan secara maksimal. Hal ini terjadi di Intitut Teknologi Sumatera (ITERA) terutama pengolahan informasi yang berkaitan dengan performansi mahasiswa. Hal ini karena belum tersedia tools untuk mengolah data menjadi informasi. Selain itu meningkatnya jumlah mahasiswa yang drop out (DO), mengulang dan tidak melanjutkan perkuliahan pada tahun pertama menjadi hal yang sangat mendasar diperlukanya tools tersebut. Oleh karena itu untuk membantu jalananya proses bisnis perguruan tinggi agar dapat membuat dan menghasilkan keputusankeputusan tepat, cepat dan lebih baik, dibuat sebuah dahsboard yang diharapkan dapat menjadi penyedia informasi yang akurat, mudah dan cepat.

Dahsboard merupakan aplikasi yang menyediakan informasi secara periode dan realtime yang menampilkan nilai key performance indicators (KPI) dengan menggunakan media penyajian yang efektif [2]. Dashboard digunakan oleh top level management perguruan tinggi dalam menganalisis informasi. Pengembangan dashboard membutuhkan suatu penyimpanan data dalam bentuk data warehouse. Karena data warehouse memberikan kemudahan dalam pengambilan data [3].

Pada penelitian [3][4] memperlihatkan bahwa penggunaan data warehouse dalam proess analisis data pada dashboard lebih efektif dibandingkan penggunaan langsung pada basis data operasional (OLTP). Bahkan data warehouse juga menjadi dasar untuk melakukan analisis dengan data mining [5]. Implementasi data warehouse pada bidang akademik di perguruan tinggi dilakukan oleh [6]. Namun penelitian tersebut tidak spesifik membahas detail tentang performansi mahasiswa.

Berdasarkan penjelasan di atas terdapat 2 hal yang dilakukan dalam penelitian ini yaitu proses penyimpanan dengan data warehouse dari semua data yang diperlukan dan membuat dashboard dari data warehouse yang dibangun. Oleh karena itu penelitian ini bertujuan mengembangkan data warehouse perguruan tinggi dengan objek perfomansi mahasiswa dan aplikasi dahsboard untuk proses monitoring berbasis open source software.

\section{Metodologi Penelitian}

Metodologi penelitian yang digunakan mengacu pada metode simon's four phase sebagai the decision making modelling process [7] yang meliputi tahap intelligence, perancangan (design), pemilihan (choice) dan implementation. Tahap intelligence merupakann tindakan melihat lingkungan sistem bertujuan untuk mengidentifikasi permasalahan. Tahap perancangan merupakan tahap modelkan permasalhan yang didapatkan sedangkan pemilihan dan implementation adalah tahapan untuk memilih teknik penyelesaian masalah, verifkasi dan validasi. Metode tersebut dapat dilihat pada Gambar 1. 


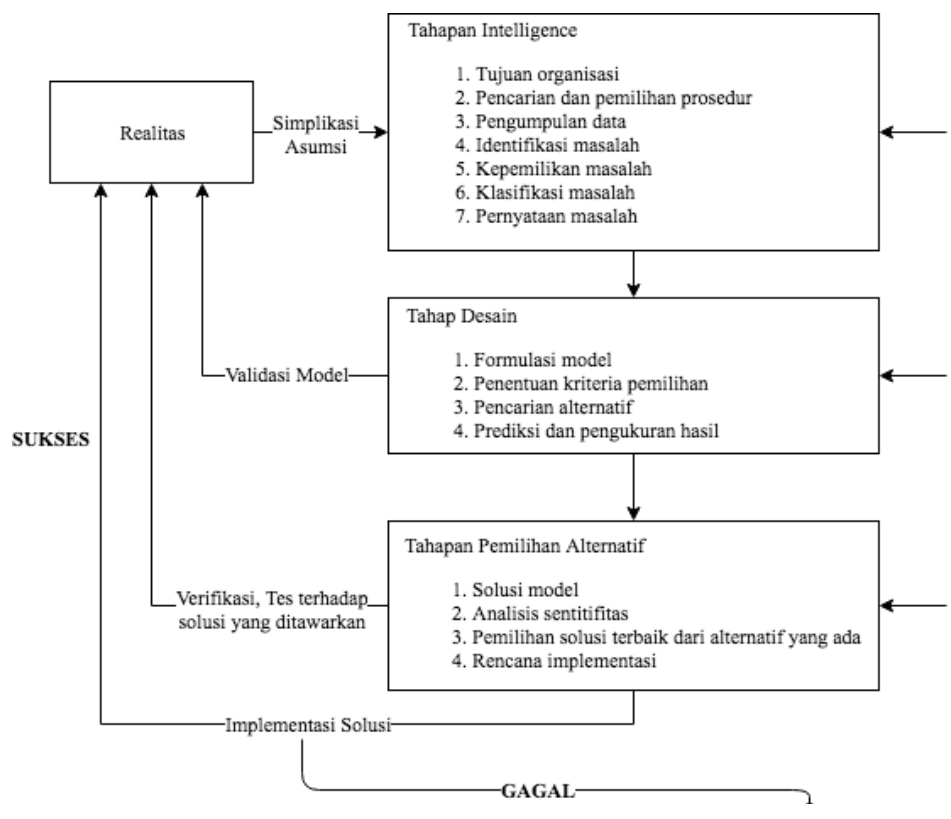

Gambar 1. Langkah-langkah pembuatan DSS [7]

Secara garis besar penelitian ini terdiri dari 2 tahapan, yaitu perancangan dan implementasi data warehouse dan membuat prototype aplikasi dashboard untuk sistem pendukung keputusan. Aplikasi dashboard untuk menampilkan data dari data warehouse. Adapun detail yang digunakan pada setiap tahapan yang mengacu pada Gambar 1 dalah sebagai berikut:

1. Tahapan perancangan dan implementasi data warehouse

Pada tahapan ini bertujuan untuk menyiapkan data warehouse dari berbagai sumber data. Adapun tahapan ini terdiri dari beberapa tahapan, yaitu:

a. Tahapan analisis.

Tahapan ini dilakukan analisis kebutuhan dan analisis data dan data sumber yang dibutuhkan dalam membangun data warehouse.

b. Tahapan desain.

Tahapan ini terdiri dari proses perancangan arsitektur sistem data warehouse dan teknologi yang akan digunakan. Tahap ini meliputi perancangan skema basis data, perancangan tabel dimensi dan tabel fakta, menentukan pemetaan tabel dan kolom pada data sumber. Tahapan ini diimplementasikan pada DBMS.

c. ETL.

Tahapan ini terdiri datai proses ekstraksi, transformasi dan loading (ETL) dari data sumber ke data warehouse. Proses ETL pada penelitian ini menggunakan apache airflow. Apache airflow merupakan aplikasi workflow yang dikembangkan oleh Airbnb dengan bahasa pemrograman python.

d. Testing.

Tahapan untuk mengetahui fungsionalitas sistem berjalan dengan baik.

2. Tahapan pembuatan prototype aplikasi dashboard.

Pada tahapan ini bertujuan untuk membuat aplikasi dashboard dari data warehouse yang telah dibangun.

a. Tahapan analisis. 
Mengindetifikasi kebutuhn data yang akan divisulasisasikan dari data warehouse.

b. Tahapan desain.

Mengidentifikasi dan mempelajari bentuk dashboard sesaui dengan data. Tahap ini mempelajari dan menentukan jenis visualiasi yang umum pada sistem dashboard dan memetakannya sesuai dengan hasil tahapan analisis.

c. Pengembangan aplikasi dashboard

Aplikasi dashboard akan dibangun menggunakan framework codeigniter dengan bahasa pemrograman PHP dan frameword dashboard D3.js

d. Testing

Tesing dilakukan berdasarkan fungsional testing yang akan menampilkan apakah aplikasi dashboard sudah sesuai dengan kebutuhan fungsional.

\section{Hasil dan Pembahasan}

\subsection{Perencanaan dan Implementasi Data Warehouse}

Tahapan pertama dalam pengembangan data warehouse adalah menganalisis kebutuhan data yang berhubungan dengan performansi mahasiswa. Proses analisis dilakukan pada sistem informasi akademik (SIA), pangkalan data perguruan tinggi (PDPT) ${ }^{1}$, dokumen penunjang seperti borang akreditasi [8], peraturan akademik ITERA [9], standar nasional DIKTI [10] dan SPM DIKTI [11]. Adapun hasil analisis dapat dilihat pada Tabel 1.

Tabel 1. Hasil analisis kebutuhan

\begin{tabular}{|l|l|}
\hline Kategori data & Jenis informasi \\
\hline Pmb & Profil mahasiswa berdasarkan tahun masuk dan propinsi asal \\
\hline & Rasio mahasiswa diterima seleksi dan daftar ulang setiap jalur masuk \\
\hline Akademik & Profil mahasiswa per tahun angkatan berdasarkan satus akademik \\
\hline & Profil mahasiswa cuti, do, mengundurkan diri dan lulus \\
\hline & Profil mahasiswa perpanjang studi \\
\hline & Profil mahasiswa tpb bermasalah \\
\hline & Profil mahsiswa semester akhir \\
\hline & Lulusan berdasarkan tahun, ipk, lama studi dan penyelesaian tugas akhir \\
\hline & Rata-rata indeks prestasi kumulatif (ipk) selama lima tahun terakhir. \\
\hline & Penghargaan atas prestasi mahasiswa di bidang nalar \\
\hline & Persentase kelulusan tepat waktu. \\
\hline & Persentase mahasiswa yang do atau mengundurkan diri. \\
\hline & Persen lulusan tepat waktu dengan masa studi 4 tahun \\
\hline & Persen lulusan dengan ipk $\geq 3,0$ \\
\hline & Persen lulusan berpredikat cumlaud \\
\hline & Persen lulusan dengan masa tunggu kerja $\leq 3$ bulan \\
\hline & Rasio jumlah lulusan angkatan : mahasiswa baru angkatan tersebut \\
\hline & Rasio jumlah lulusan : jumlah mahasiswa terdaftar \\
\hline & Rasio jumlah mahasiswa do : jumlah mahasiswa baru \\
\hline & Persentasi tingkat kelulusan mahasiswa tepat waktu \\
\hline & Masa tunggu kerja pertama (dalam bulan). \\
\hline & \\
\hline &
\end{tabular}

\footnotetext{
${ }^{1}$ http://forlap.dikti.go.id
} 
Pada Tabel 1 terdapat kategori data. Penentuan kategori data berdasarkan pada perjalanan proses bisnis akademik pada perguruan tinggi yaitu data penerimaan mahasiswa baru (PMB), proses akademik dan KPI. Data PMB berasal dari sistem informasi PMB dan sistem informasi data induk mahasiswa (DIM), data proses akademik berasal dari sistem informsi akademik (SIA) dan KPI berasal dari sistem informasi alumni, SIA dan DIM.

Berdasarkan analisis kebutuhan maka aplikasi dashboard yang dibuat akan dapat:

- Menampilkan secara visual sebaran mahasiswa berdasarkan tahun masuk, asal provinsi dan jalur masuk perguruan tinggi.

- Menampilkan perbandingan jumlah mahasiswa yang mengambil cuti, DO, mengundurkan diri dan lulus pada setiap tahun ajaran

- Menampilkan jumlah mahasiswa yang bermaslah pada tahun pertama perkuliahan, baik mahasiswa mengulang, mengundurkan diri dan tanpa keterangan.

- Menampilkan performansi lulusan setiap tahun akademik dengan melihat rata-rata IPK, lama studi, lama penyelesain tugas akhir.

- Menampilkan nilai-nilai KPI yang berhubungan dengan proses akademik mahasiswa dan lulusan.

Selain itu berdasarkan hasil analisis kebutuhan data dan inforasi yang akan ditampilkan pada aplikasi dashboard maka dibuat skema tabel dimensi dan fakta. Tabel dimensi dan fakta untuk data warehouse akademik performansi mahasiswa dapat dilihat pada Gambar 2.

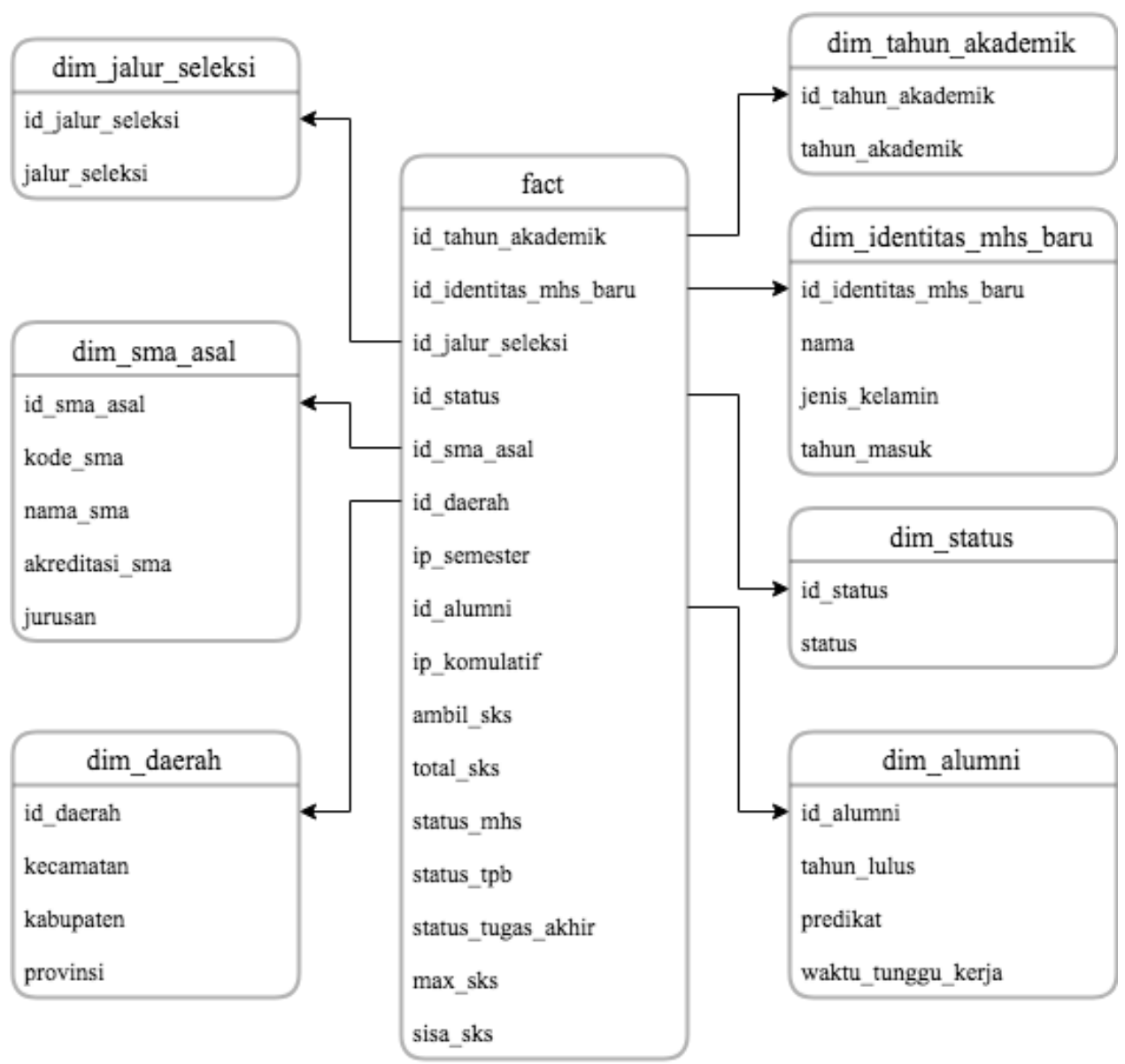

Gambar 2. Tabel dimensi dan fakta data warehouse akademik performansi mahasiswa 
Skema data warehouse akademik performansi mahasiswa menggunakan skema bintang. Hal ini karen skema binta memiliki performansi yang lebih baik pada proses pencarian data. Berdasarkan pada Gambar 2, skema bintang akademik performansi mahasiswa terdiri dari tujuh tabel dimansi dan satu tabel fakta. Dim_jalur_seleksi berisi informasi jalur seleksi masuk perguruan tinggi dari setiap mahasiswa. Dim_sma_asal berisi informasi asal SMA mahasiswa. Dim_daerah berisi informasi asal daerah mahasiswa. Dim_indentitas_mhs merupakan detail informasi terkait identitas seperti jenis kelamin, nama dan tahun masuk. Dim_akademik berisi atribut tahun akademik perguruan tinggi. Dim_status berisi status mahasiswa seperti, lulus, DO, undur diri (unri) dan cuti. Sedangkan dim_alumni berisi informasi setelah lulus mahasiswa seperti waktu tunggu kerja. Berdasarkan pada tabel dimensi dan fakta, maka dilakukan proses ELT dari basis data sumber seperti SIA, DIM, PMB dan alumni. Proses ETL dilakukan dengan menggunaka apache airflow ${ }^{2}$.

\subsection{Prototype Aplikasi Dashboard}

Arsitektur penggembangan dashboard pada penelitian ini mengadopsi arsitektur threetier. Pada lapisan bawah adalah pemrosesan data dan pembuatan skema data warehouse dengan DBMS MariaDB 10.0.19. Di lapisan tengah terdapat web server yang digunakan untuk proses penjalankan aplikasi dahboard dengan menggunakan apache. Aplikasi dashboard dikembangan dengan menggunakan framework codeigniter (bahasa pemrograman PHP). Di lapisan atas visualisasi dari aplikasi dilakukan oleh web browser. Di lapisan ini pengguna dapat melakukan pencarian data, mengevaluasi pola, dan mendapatkan representasi informasi dalam bentuk yang mudah dipahami. Arsitektur three-tier data warehousing pada penelitian ini dapat dilihat pada Gambar 3.

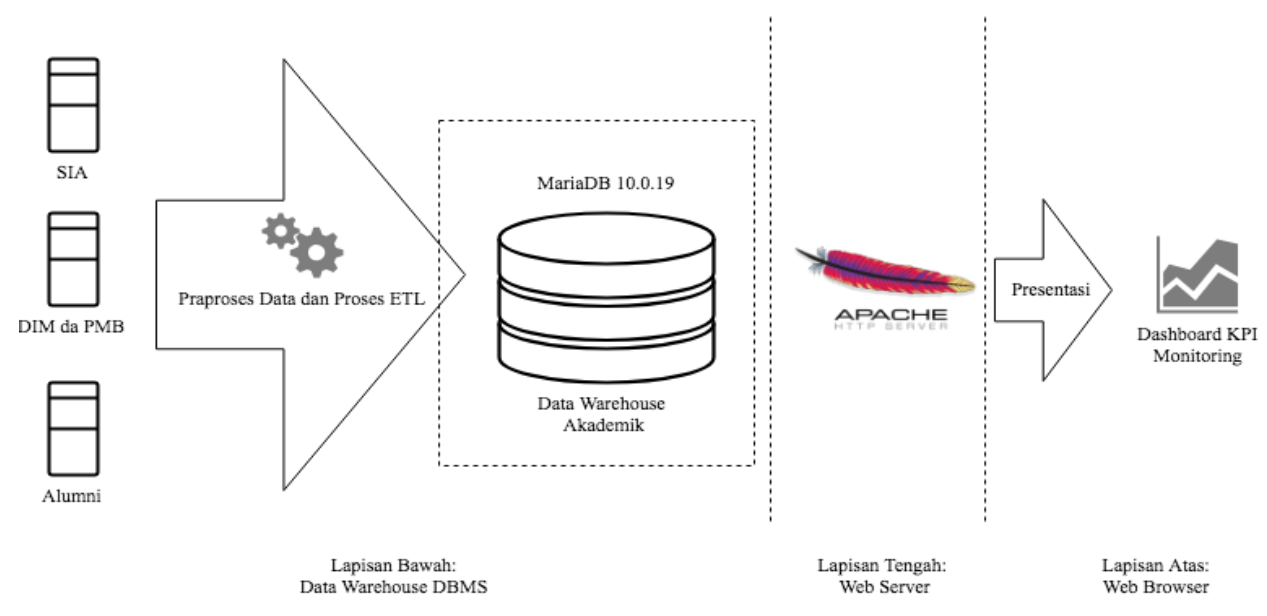

Gambar 3. Arsitektur data warehouse dan aplikasi dashboard

Berdasarkan arsitektur pada Gambar 3, aplikasi dashboard dikembangan dengan menggunakan sumber data dari data warehouse. Gambar 4 menunjukkan antarmuka aplikasi dashboard unutk memonitoring performansi mahasiswa.

\footnotetext{
${ }^{2}$ https://airflow.apache.org/
} 


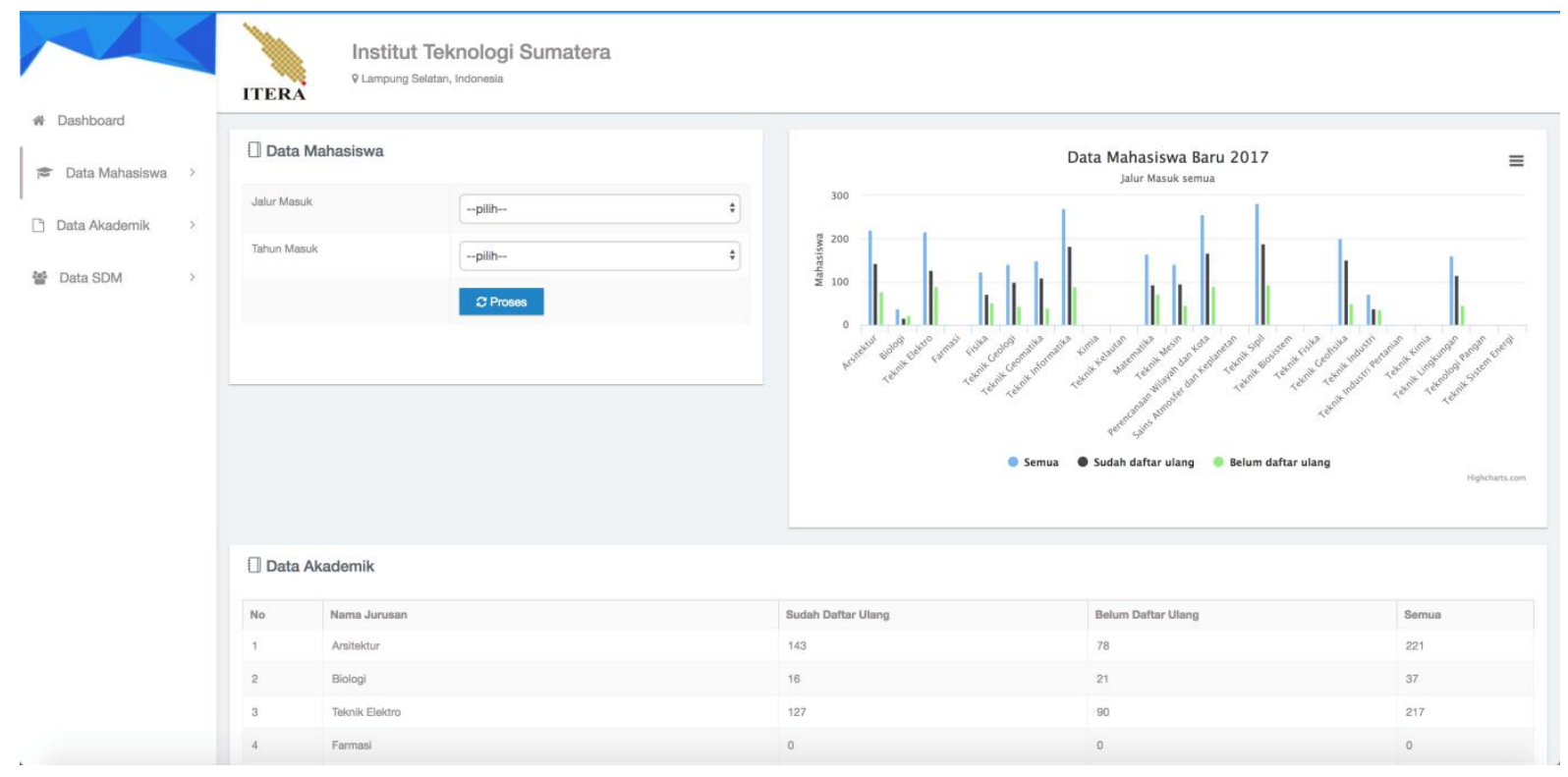

Gambar 4. Antarmuka aplikasi dashboard

Setelah aplikasi dashboard berhasil dikembangkan sesuai dengan hasil analisis kebutuhan, dilakukan pengujian utama fitur aplikasi. Fitur utama dari dashboard ini adalah menampilkan sebaran mahasiswa berdasarkan tahun masuk, asal daerah dan jalur masuk perguruan tinggi, menampilkan perbandingan mahasiswa pada setiap tahun akademik berdasarkan status mahasiswa, menampilkan mahasiswa yang bermasalah pada tahun pertama perkuliahan, menampilkan performansi mahasiswa setiap tahun akademik dan menampilkan KPI terkait dengan hasil proses akademik. Hasil pengujian untuk fitur-fitur utama dashboard terdapat pada Tabel 1. Hasil pengujian menunjukkan fitur-fitur utama dashboard dapat bekerja dengan baik dan menghasilkan keluaran yang sesuai dengan skenario pengujian. Namun penelitian ini, belum dapat melakukan operasi-operasi Online Analytical Processing (OLAP).

Tabel 2. Hasil pengujian aplikasi dashboard

\begin{tabular}{|c|c|c|c|}
\hline Fitur & Skenario Pengujian & Hasil yang Diharapkan & Status Pengujian \\
\hline $\begin{array}{l}\text { Sebaran } \\
\text { mahasiswa } \\
\text { berdasarkan } \\
\text { tahun masuk, } \\
\text { asal daerah dan } \\
\text { jalur masuk } \\
\text { perguruan tinggi }\end{array}$ & $\begin{array}{l}\text { Pengguna memilih } \\
\text { tahun masuk } \\
\text { perguruan tinggi dan } \\
\text { menekan tombol } \\
\text { "Proses" }\end{array}$ & $\begin{array}{l}\text { Sebaran mahasiswa } \\
\text { berdasarkan asal daerah } \\
\text { dan jalur masuk. Serta } \\
\text { menampilkan jumlah } \\
\text { masiswa berdasarkan } \\
\text { tahun masuk yang } \\
\text { dipilih. }\end{array}$ & Sesuai \\
\hline $\begin{array}{l}\text { Perbandingan } \\
\text { mahasiswa pada } \\
\text { setiap tahun } \\
\text { akademik } \\
\text { berdasarkan } \\
\text { status } \\
\text { mahasiswa }\end{array}$ & $\begin{array}{l}\text { Pengguna memilih } \\
\text { tahun akademik } \\
\text { perguruan tinggi dan } \\
\text { menekan tombol } \\
\text { "Proses" }\end{array}$ & $\begin{array}{l}\text { Menampilkan grafik } \\
\text { stacked bar yang } \\
\text { menampilkan informasi } \\
\text { jumlah mahasiswa } \\
\text { berdasarkan statusnya } \\
\text { (DO, Lulus, } \\
\text { mengundurkan diri, dan } \\
\text { tanpa keterangan) pada } \\
\text { tahun akademik yang }\end{array}$ & Sesuai \\
\hline
\end{tabular}




\begin{tabular}{|l|l|l|l|}
\hline Fitur & Skenario Pengujian & Hasil yang Diharapkan & Status Pengujian \\
\hline $\begin{array}{l}\text { Mahasiswa yang } \\
\text { bermasalah pada } \\
\text { tahun pertama } \\
\text { perkuliahan }\end{array}$ & $\begin{array}{l}\text { Pengguna memilih } \\
\text { tahun akademik } \\
\text { perguruan tinggi dan } \\
\text { menekan tombol } \\
\text { "Proses" }\end{array}$ & $\begin{array}{l}\text { Menampilkan grafik } \\
\text { stacked bar yang } \\
\text { menampilkan informasi } \\
\text { jumlah mahasiswa } \\
\text { berdasarkan statusnya } \\
\text { pada tahun pertama } \\
\text { perkuliahan (Mengulang } \\
\text { mata kuliah tahun } \\
\text { pertama, Lulus, } \\
\text { mengundurkan diri, tanpa } \\
\text { keterangan) pada tahun } \\
\text { akademik yang dipilih }\end{array}$ & Sesuai \\
& $\begin{array}{l}\text { Menampilkan grafik } \\
\text { stacked bar yang } \\
\text { menampilkan informasi } \\
\text { rata-rata IPK, lama studi } \\
\text { dan penyelesaian tugas } \\
\text { akhir mahasiswa pada } \\
\text { tahun akademik yang } \\
\text { mahasiswa } \\
\text { setiap tahun } \\
\text { akademik }\end{array}$ & $\begin{array}{l}\text { Pengguna memilih } \\
\text { tahun akademik } \\
\text { perguruan tinggi dan } \\
\text { menekan tombol } \\
\text { "Proses" }\end{array}$ & Sesuai \\
& $\begin{array}{l}\text { Menampilkan KPI pada } \\
\text { Tabel 1. }\end{array}$ & Sesuai \\
\hline KPI & Pengguna ketika & \\
\hline
\end{tabular}

\section{Kesimpulan}

Hasil dari penelitian ini berupa data warehouse perguruan tinggi dengan objek perfomansi mahasiswa yang digunakan oleh aplikasi dashboard. Selain itu konsep penelitian ini diharapkan dapat diimplementasikan diperguruan tinggi lain atau perusahaan. Seluruh fitur dashboard telah dilakukan pengujian dan berkerja sesuai dengan skenario pengujian.

\section{Ucapan Terimakasih}

Penelitian ini didanai oleh Kementerian Riset Teknologi dan Pendidikan Tinggi pada Program Penelitian dosen Pemula (PDP)

\section{Daftar Pustaka}

[1] Asmawi, M. R. (2010). Strategi meningkatkan lulusan bermutu di perguruan tinggi. Hubs-Asia, 9(2).

[2] Hariyanti, E. (2008). Metodologi Pembangunan Dashboard sebagai Alat Monitoring Kinerja Organisasi Studi Kasus Institut Teknologi Bandung. Institut Teknologi Bandung.

[3] Suryani, K. N., \& Laksmiwati, H. (2012). Evaluasi Teknik Optimalisasi Proses ETL dan Skema Data Warehouse untuk Mendukung Tactical Business Intelligence. Jurnal Sarjana ITB bidang Teknik Elektro dan Informatika, 1(2).

[4] Warnars, S. (2010). Tata kelola database perguruan tinggi yang optimal dengan data warehouse. arXiv preprint arXiv:1006.1663. 
[5] Ranjan, J., \& Khalil, S. (2008). Conceptual framework of data mining process in management education in India: An institutional perspective. Information Technology Journal, 7(1), 16-23.

[6] Azimah, A., \& Sucahyo, Y. G. (2007). Implementasi Data Warehouse Untuk Menunjang Kegiatan Akademik. In Seminar Nasional Sistem dan Informatika (Vol. 12, pp. 1-12).

[7] Turban, E., Sharda, R., \& Delen, D. (2014). Decision support and business intelligence systems (Vol. 9). Pearson.

[8] https://banpt.or.id/instrumen/Perban/Buku_III_Borang_Akreditasi_APTTJJ.pdf

[9] http://www.itera.ac.id/wp-content/uploads/2017/08/PERATURAN-AKADEMIK-DANKEMAHASISWAAN-ITERA-2017.pdf

[10] https://bsnp-indonesia.org/wp-content/uploads/2017/09/permenristekdikti-nomor-55tahun-2017.pdf

[11] http://spmi.ristekdikti.go.id/uploads/publications/Buku\%20Pedoman\%20SPMI\%20201 8.pdf 